\title{
THE APPLICATION OF LESSON STUDY ASSISTED BY TWO STAY TWO STRAY COOPERATIVE MODEL TO IMPROVE ACTIVENESS AND LEARNING OUTCOMES OF ELEMENTARY SCHOOL STUDENTS
}

\author{
Nilamsari Damayanti fajrin ${ }^{1 *}$, Sisca Wulandari ${ }^{2}$ \\ ${ }^{1}$ Faculty of Education, Universitas Trunojoyo Madura, Indonesia \\ ${ }^{2}$ Ganesha Institute, Indonesia
}

Corresponding 1*nilamsari.damayantifajrin@trunojoyo.ac.id; 2wsisca31@gmail.com

DOI: https://doi.org/10.21107/Widyagogik/v8i1.8745

Received October 3, 2020; Revised October 16, 2020; Accepted October 30, 2020

\begin{abstract}
The purpose of this study is to determine the effectiveness of the application of lesson study in improving the quality of elementary school learning. The improvement of learning quality can be seen from two indicators, which are increasing student activeness and student learning outcomes. The type of this research is a qualitative descriptive study. The subjects of research was the students of class IVC at SDN Tunjungsekar 1 as many as 30 students. The implementation of the study used 2 stages which is consisted of the first stage, which was conducted by observing the activeness and getting the learning outcomes in conventional learning; and the second step, in which the lesson study step, consisting planning, doing, and seeing, assisted by the cooperative model TSTS was conducted. The results showed that the IVC grade students of SDN Tunjungsekar 1 experienced an increase in activeness by $46.90 \%$ from the first meeting to the second meeting, besides that was also there an increase in learning outcomes by $18.81 \%$ from the first meeting to the second meeting. Then, it can be concluded that the application of the learning type of TSTS cooperative in lesson study can increase student activeness and learning outcomes
\end{abstract}

Keywords: Lesson Study, Two Stay Two Stray (TSTS), Active Learning, Learning Outcomes 
35 The Application of Lesson Study Assisted by Two Stay Two Stray Cooperative Model to Improve Activeness And Learning Outcomes Of Elementary School Students

Nilamsari Damayanti fajrin, Sisca Wulandari

\section{Introduction}

Learning in Indonesian elementary schools applies the revised 2018 curriculum with typical thematic learning. Thematic learning is integrated learning that uses themes (KEMENDIKBUD, 2013:8). Akbar (2013:69) states that there are four thematic learning characteristics, namely holistic (studying several subjects at once), meaningful (functional for student life), authentic (direct learning experience), and active (involving students in planning, implementing, and evaluating the learning). While Majid (2014:17) states thematic learning is a learning approach that raises themes that are close to the lives of students and their environment so that they are meaningful and can provide experiences for their lives and future. Thematic learning applied to the 2013 Curriculum is expected to increase the activeness and learning outcomes of the elementary school students. There are three learning models that are formulated, namely problem based learning, project based learning, and discovery learning or discovery methods (KEMENDIKBUD, 2013).

During the initial observation and interview during the Lecture and Field Practice activities in class IVC at SDN Tunjungsekar 1, several problems were encountered by students and teachers. The problems experienced by students were (1) only intelligent students who often participate in learning. While students who are less smart rarely participate; (2) learning often only comes from the books of students and teachers and does not use or involve the environment as a source of learning; and (3) when a student's grade is checked that day, most students get grades below the Minimal Learning Completeness.

For the problem, one of cooperative learning models can carry out the learning, it was the Two Stay Two Stray (TSTS) model. Two Stay Two Stray (TSTS) was a technique that divided students into several groups, a group contains four students, two students stay to receive visitor from other groups and two students stray to the other groups. Two Stay Two Stray (TSTS) maked learning more enjoyable, created their ideas and shared with their friends in groups to achieve their learning goal in which they work together to share their understanding about the text, of course, the topics which were related to academic materials (Hidayat \& Muhson, 2018). TSTS was a cooperative learning model that can improve student activiness and learning outcomes (Hidayat \& Muhson, 2018, \& Wardana, Setyani, \& Harwida, 2018).

The problems experienced by the teacher were (1) the teacher confessed difficulties in attracting students' interest to actively ask questions and be actively involved; (2) teachers were not really able to choose the right learning model for students' daily meetings, teachers claimed to only randomly change the three models recommended by the 2013 Curriculum; and (3) the teacher felt ashamed to ask other teachers for fear of being considered incompetent. Based on the problems of students and teachers, we need a solution that can overcome them, one of the most appropriate solutions is to apply lesson study. 
Lesson study has the aim to improve the professionalism of teachers in designing learning quality. Lesson study was a process by which educators work together to critically improve the quality of classroom practice through a planning, observation, and reflection cycle (Suratno \& Cock, 2009). Lesson study researches in Indonesia (Liliawati \& Hikmat, 2007; Daryanti, 2007; \& Maria \& Supriyanti, 2007) showed that there are many studies on how to develop an engaging lessons. Lesson study has three steps, namely plan, do, and see. In addition, lesson study is carried out in the form of teacher groups, and that teachers can help each other and discuss to determine better learning going in the future. So, in this research, to improve activeness and learning outcomes of the student, researcher applicated the lesson study assited by TSTS cooperative learning.

\section{Method}

This research was descriptive qualitative research. This research was focus on activeness and learning outcomes. This research explained teacher activity and students for two meetings. In the first meeting, the first model teacher implemented conventional learning without following the stage of Lesson Study. In the second meeting, second model teachers implemented learning model two Stay Two Stray (TSTS) by following Lesson Study stage (Plan, Do and See).

The subjects of research was the students of class IVC at SDN Tunjungsekar 1 as many as 30 students, 15 female students and 15 male students. At the first meeting, the homeroom teacher of class IVC acted as the first model teacher, while the researcher and the other teachers of class of IV acted as observer. At the second meeting, lesson study was done. It included: (1) the Plan stage contained the discussion activity of the discussion about desigining the learning which would be conducted in the second meeting. (2) the Do stage is the stage of implementing the plan and observing the learning process. The researcher acted as model teacher, while the homeroom teacher and other researcher acted as observer; and the See stage consisted of discussion activity and learning reflection. This stage was followed by model teacher, three homeroom teachers of class IV, the researcher, and other member of researcher.

Research data in the form of student activeness was collected through observation sheets, video footage, and anecdotal notes. Research data in the form of student learning outcomes were collected through a test sheet.

\section{Result And Discussion}

\subsection{Result}

\subsubsection{Meeting Two without Lesson Study}

In the first meeting, the first model teacher got the Theme 3 Sub theme 3 "Let's Love the Environment!" the 1st learning. The material tends to include the content of science and because of the first learning, the learning activities should provide links and insights to the sub-themes which were being discussed. In the first lesson, the material 
37 The Application of Lesson Study Assisted by Two Stay Two Stray Cooperative Model to Improve Activeness And Learning Outcomes Of Elementary School Students

Nilamsari Damayanti fajrin, Sisca Wulandari

which was discussed was about the treated environment and the untreated environment. The model teacher arranged a Learning Implementation Plan independently. Learning Implementation Plans which were made by the teacher model was in the form of powerpoint presentations of various environmental examples and then conducting question and answer session and group discussions.

The first learning activity is carried out for $2 \times 35$ minutes. Learning activities was opened with greetings, praying, and attendance. In the apperception activity, the students were asked to ask questions about the GSF (Green School Festival) Contest which was held in the previous September because it was related to the sub-themes and material to be studied, namely Theme 3 Sub-theme 3 "Let's Love the Environment!" (the material about the treated environment and untreated environment). At the apperception time, students were very excited and they answered the questions with various answers. When the teacher got an answer related to the theme, the teacher related it with the material that was being studied. After that, the students paid attention to the teacher's explanation of the objectives to be achieved through learning activities that will be carried out.

The core learning activities include viewing PowerPoint and watching videos. During this activity, there were 5 students who yawned, and 4 students who talked with their peers. Students look bored. After that, students are given group assignments. Each group consists of five people, except group 6 only consists of three people because there are two students who did not come that day. The teacher distributed the worksheets and the students start working on the worksheets. During this activity there were 2 students who did not understand the purpose of the worksheet distributed by the teacher, there were some group members, who had finished working, disturbed their friends who had not finished working on it. After finishing, each group presented the results of their discussion in front of the class and other students were given the opportunity to give their responses. Then students paid attention to the reinforcement given by the teacher.

The final learning activity was carried out by concluding together about the characteristics of the treated environment and untreated environment, as well as giving a moral message to always care and preserve the environment around students. Then the students were asked to work on evaluation questions. After that the activity was closed by doing reflection, saying hamdalah, and greetings.

Reflection activities based on observations by observers were (1) the selection of learning models was not appropriate because it was only related with the classroom, it should be able to use a learning model that invites students to unite with nature or the school environment; (2) the division of groups was less proportional because there were homogeneous groups and heterogeneous groups based on sex. (3) Groups 5 and 6 are passive and still shy or lack of confidence. 


\subsubsection{Meeting Two using Lesson Study}

The plan for the second meeting of the lesson study was based on the results of the reflection from the observation sheet of the first meeting and the materials which were obtained from the homeroom teacher. In the second meeting, the model teacher got material from the homeroom teacher, namely Theme 4 Sub-theme 1 "Types of Work". The researcher designed the activity by applying the TSTS learning model because the material contained social studies so that the students could explore information through exhibitions in class and learn to socialize with their friends.

The second lesson study learning activity was carried out for $2 \times 35$ minutes. Learning activities were opened with greetings, praying, and attendance. In apperception activities students were asked to ask questions about the natural appearance in Malang Raya and the type of works that is identical to the place. Students answered the questions with great enthusiasm and with various answers, but with the guidance of the teacher directed to relate to the material discussed (type of work based on natural appearance). After that, students pay attention to the teacher's explanation of the objectives to be achieved through learning activities that will be carried out.

The core learning activities included several activities of which steps refer to the cooperative type TSTS model. First, students made groups according to the division that had been done previously by the teacher based on gender heterogeneity and academic ability. The students were divided into 6 groups based on the type of work discussed, including farmers, teachers, entrepreneurs, fishermen, tour guides, and breeders. Then, the students prepared equipment for group work and cooperate to create a wall magazine (bulletin board) that explains about each job (content of the bulletin: equipment for work, tasks which are performed, and the importance of the type of work for the community). Students are given time to work for 30 minutes, but in reality students need more time which is about 45 minutes. The next activity was a presentation and exhibition, where two group members stayed to explain the results of the bulletin they made and three people visited other groups to gather information about various other types of work. The situation and condition of the class became crowded and noisy. Some students seemed to be joking with their friends, especially male students, but were then re-conditioned by the teacher. Students then returned to their respective groups and shared information with friends who stayed about the results of the interview. The teacher asked a confident group (farmer group) to present their work. Then the teacher gave the opportunity to other groups who had different answers to complete. Students are given the opportunity to ask if there is material that they had not understood yet. Then, the students were given reinforcement about various types of work which can be found in their surroundings through PowerPoint slides. 
39 The Application of Lesson Study Assisted by Two Stay Two Stray Cooperative Model to Improve Activeness And Learning Outcomes Of Elementary School Students

Nilamsari Damayanti fajrin, Sisca Wulandari

The final learning activity was carried out by concluding together about examples of types of work based on their natural place or appearance, as well as giving a moral message to always have high ideals and realize them by actively trying through diligent study and prayer. Then students were asked to work on five evaluation questions and the first number question was to write down their goals. After that the activity was closed by doing reflection, saying hamdalah, and greetings.

Reflection activities based on observations by the observer at the second meeting were as follows: (1) The giving of instructions was unclear, so the teacher needs to serve the questions from each group; (2) Students were very happy with the learning activities carried out, it could be seen when students were reluctant to take a break time and ask to continue to carry out learning even though it was time for other subject, that is Javanese language lessons; (3) Students were able to develop an attitude of cooperation, mutual respect, and responsibility in groups, and students' creativity was very unique, seen from their work of bulletin.

\subsubsection{The Activeness of The Students}

As stated in the method research, the first effectiveness indicator of the lesson study application is increasing student activity. Indicators of activeness that must be achieved by students include (1) asking questions; (2) submit opinions; (3) answering questions; (4) discussion; (5) pay attention to teacher explanations; (6) work on LKS; and (7) participate in games / activities. In this research, students are considered (1) very active when implementing 6-7 indicators; (2) active if implementing 3-5 indicators; (3) less active if implementing 2 indicators; and (4) not active if implementing 1 indicator (such as working on LKS) or if they don't show the indicator at all.

At the first meeting, there were 28 student because 2 students were sick. The results of the observation sheet, video recording, and anecdotal notes at the first meeting showed that there were 4 very active students, 9 active students, 11 less active students, and 4 inactive students. While at the second meeting, students present were full, there were 30 students. The results of the observation sheet, video recording, and anecdotal notes at the second meeting showed that there were 16 very active students, 12 active students, 2 less active students, and 0 inactive student.

Based on the results of the students activeness of the IVC grade SDN Tunjungsekar 1 , it is known that before the application of lesson study, at the first meeting students who were in the active and very active category amounted to $46.43 \%$, while students who were in the less active and inactive category were $53.57 \%$. After applying lesson study at the second meeting, students in the active and very active category were $93.33 \%$, while students in the less active and inactive category were $6.67 \%$. It can be seen that there was an increase in the activeness of $46.90 \%$ from the first meeting to the second meeting. Therefore, it can be said that lesson study can increase the activeness of the students. 


\subsubsection{Student Learning Outcomes}

As stated in the method research, the second effectiveness indicator of the lesson study application is increasing student learning outcomes. Student learning outcomes can be said to have increased if the average classical completeness of the meeting second is higher than the average classical completeness of the first meeting. Students are considered complete if the individual scores student above the Minimum Learning Complete (KBM) are equal to or more than 75 .

At the first meeting, there were 28 students because 2 students were sick. The results of the test sheet at the first meeting showed that 19 students scored above the KBM and 9 students got grades below the KBM. While at the second meeting, students present were full, there were 30 students. The results of the test sheet at the second meeting showed that 26 students scored above the KBM and 4 students got grades below the KBM.

Based on the students learning outcomes of the IVC grade SDN Tunjungsekar 1, it is known that before the application of lesson study, at the first meeting, the average classical completeness of student learning outcomes was $67.86 \%$. Whereas, after the application of lesson study at the second meeting, the average classical completeness of student learning outcomes was $86.67 \%$. It can be seen that there was an increase of $18.81 \%$ from the first meeting to the second meeting. Therefore, it can be said that lesson study can improve student learning outcomes.

\subsection{Discussion}

The results of the students activeness of the IVC grade SDN Tunjungsekar 1 showed that there was an increase in the activeness of $46.90 \%$ from the first meeting to the second meeting. Based on that, the application of the lesson study assited by TSTS cooperative learning was successfull. It was mean that not only intelligent students who often participate in learning but students who are less smart often participate in learning too. This happened because lesson study assited Two Stay Two Stray (TSTS) maked the learning more enjoyable, created their ideas and shared with their friends in groups to achieve their learning goal in which they work together to share their understanding about the text, of course, the topics which were related to academic materials (Hidayat \& Muhson, 2018). TSTS was a cooperative learning model that can improve student activeness (Wardana, Setyani, \& Harwida, 2018).

The results of the students learning outcomes of the IVC grade SDN Tunjungsekar 1 showed that there was an increase in the activeness of $18.81 \%$ from the first meeting to the second meeting. Based on that, the application of the lesson study assited by TSTS cooperative learning was successfull. It was mean that students more student got good score than before and more students got grades above the Minimal Learning Completeness. This happened because lesson study assited Two Stay Two Stray (TSTS) maked the learning more enjoyable so the students could easy momorized material and could improve their learning outcomes (Wardana, Setyani, \& Harwida, 2018). 
41 The Application of Lesson Study Assisted by Two Stay Two Stray Cooperative Model to Improve Activeness And Learning Outcomes Of Elementary School Students

Nilamsari Damayanti fajrin, Sisca Wulandari

Beside of that, the students activeness and learning outcomes could improve because the teacher didn't find difficulties in attracting students' interest to actively ask questions, the teacher didn't find difficulties to choose the right learning model for students' daily meetings, and the teacher didn't feel ashamed to ask other teachers for disscussion. This happened because lesson study had the aim to improve the professionalism of teachers in designing learning quality through a planning, observation, and reflection cycle (Suratno \& Cock, 2009). Lesson study maked the teachers felt comfort to share their problem and experience (Liliawati \& Hikmat, 2007; Daryanti, 2007; \& Maria \& Supriyanti, 2007).

\section{Conclusion}

Based on the explanation of the findings and discussion showed that the IVC grade students of SDN Tunjungsekar 1 experienced an increase in activeness by $46.90 \%$ from the first meeting to the second meeting, besides that was also there an increase in learning outcomes by $18.81 \%$ from the first meeting the second meeting. Then, it can be concluded that the application of the learning type of TSTS cooperative in lesson study can increase student activeness and learning outcomes.

TSTS cooperative learning has a very positive effect on increasing student activeness because TSTS makes all students in groups active (1) ask questions; (2) submit opinions; (3) answering questions; (4) discussion; (5) pay attention to explanations teacher; (6) work on LKS; and (7) participate in games / activities.

TSTS cooperative learning also has positive impact on improving student learning outcomes because TSTS is able to make the material delivered naturally and create an atmosphere of learning that is not boring, so student learning outcomes can be improved.

In addition, the existence of lesson study makes IVC class teachers not ashamed to ask fellow teachers. Lesson study also enhances collaboration and teacher knowledge about learning. They can choose an appropriate learning method for the diverse needs of students and various types of material in the Curriculum 2013.

\section{References}

Akbar, S. (2013). Instrumen perangkat pembelajaran. Bandung: PT. Remaja Rosdakarya.

Daryanti. (2007). Developing teachers and students' self-concept through lesson study. Paper presented at National Seminar on Exchange of Experiences on Best Practices of Lesson Study, July 27th, 2007, FOMASE IUE.

Daryanto, \& Rahardjo, M. (2012). Model pembelajaran inovatif. Yogyakarta: Gava Media. 
Hidayat, T.M.,\& Muhson, A. (2018). The impact of think pair share and two stay two stray learning model towards learning outcomes and cooperation ability. Dinamika Pendidikan Journal, 13(1), 119129. http://journal.unnes.ac.id/nju/index.php/dp

Kagan, S. (1992). Cooperative learning. San Juan Capistrano: Kagan Cooperative Learning.

KEMENDIKBUD. (2013). Panduan teknis kurikulum 2013: Pembelajaran tematik terpadu dengan pendekatan saintifik di sekolah dasar. Jakarta: Kementerian Pendidikan dan Kebudayaan.

Liliawati, W. \& Hikmat. (2007). Profiles of teacher ability to observe and to reflect upon lessons, the case of subject teacher group $\mathrm{C}$ in Sumendang city. Paper presented at National Seminar on Exchange of Experiences on Best Practices of Lesson Study, July 27th, 2007, FOMASE UPI.

Majid, A. (2014). Pembelajaran tematik terpadu. Bandung: PT. Remaja Rosdakarya.

Maria, F. \& Supriyanti, T. (2007). Collegiality as a means of improving teacher self confident in conducting chemitry instruction in junior secondary schools in Situraja region. Paper presented at National Seminar on Exchange of Experiences on Best Practices of Lesson Study, July 27th, 2007, FOMASE UPI.

Mayrhofer, E. (2019). Lesson study and teachers' beliefs. International Journal for Lesson and Learning Studies, 8(1), 19-33. https://doi.org/10.1108/IJLLS-11-2018-0091

Mujasam, S.G.M., Renita, \& Allo. (2018). Activity and progress of learning with two stay two stray (tsts): Cooperative model on harmonic vibration. Journal of Turkish science education, 15 (Special Issue). http://www.tused.org

Mynott, J. (2019). Lesson study outcomes: A theoretical model. International Journal for Lesson and Learning Studies, 8(2), 117-134. https://doi.org/10.1108/IJLLS-082018-0057

Obara, S. and Bikai, N. (2019). Promoting math teacher active learning with the lesson study approach. International Journal for Lesson and Learning Studies, 8(2), 135148. https://doi.org/10.1108/IJLLS-11-2018-0088

Purwati, P. (2014). Application of two stay-two stray cooperative methods to improve student learning activities. International Journal Of Education, 3(1).

Samaranayake, G., Premadasa, K., Amarasinghe, R., \& Paneru, K. (2018). Teacher change through lesson study collaboration. International Journal for Lesson and Learning Studies, 7(4), 263-276. https://doi.org/10.1108/IJLLS-12-2017-0055

Santyasa, I W. (2009). Implementasi lesson study dalam pembelajaran. Disajikan dalam Seminar implementasi lesson study dalam pembelajaran bagi guru-guru TK, sekolah dasar, dan sekolah menengah pertama di Kecamatan Nusa Penida, 24 
43 The Application of Lesson Study Assisted by Two Stay Two Stray Cooperative Model to Improve Activeness And Learning Outcomes Of Elementary School Students

Nilamsari Damayanti fajrin, Sisca Wulandari

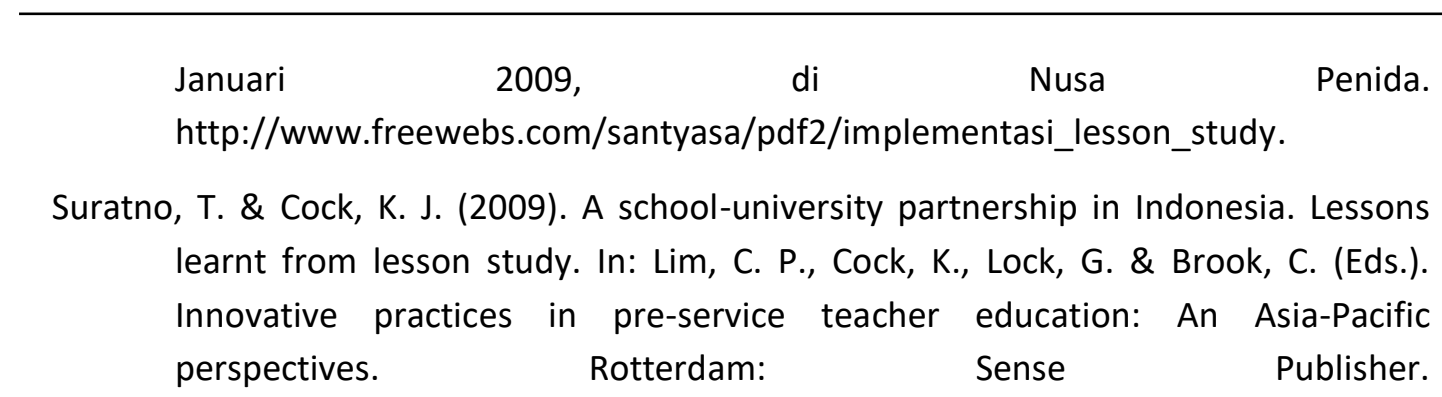

Suseno, W., Yuwono, I., \& Muhsetyo, G. (2017). Peningkatkan keaktifan dan hasil belajar siswa kelas VII pada materi sistem persamaan linear dua variabel dengan pembelajaran kooperatif TGT. Jurnal Pendidikan: Teori, Penelitian, dan Pengembangan, 2(10), 1298-1307. http://journal.um.ac.id/index.php/jptpp/ EISSN: 2502-471X DOAJ-SHERPA/RoMEO-Google Scholar-IPI

Wardana, L. W., Setyani, R., \& Harwida, G. (2018). The implementation of the two stay two stray (tsts) learning model and co-op co-op for the improvement of students' learning outcome in the crafts and entrepreneurship subject. In The First International Research Conference on Economics and Business, KnE Social Sciences, 140-149. DOI 10.18502/kss.v3i3.1880

Widhiartha, P.A \& Sudarmanto, D. (2008). Penerapan lesson study sebagai upaya peningkatan kompetensi tutor keaksaraan fungsional. Jurnal Ilmiah VISI PTKPNF, 4(1). 